\title{
Wlamyra R. de Albuquerque. 0 jogo da dissimulação. Abolição e cidadania negra no Brasil. São Paulo: Companhia das Letras, 2009.
}

Camillia Cowling

No começo de $O$ jogo da dissimulação, a historiadora Wlamyra Albuquerque espera "convencer o leitor de que, no Brasil, o processo emancipacionista foi marcado pela profunda racialização das relações sociais" (pp. 37-8). Talvez muitos leitores não precisem de muita persuasão sobre este ponto. Porém, depois de embarcarem com Albuquerque em uma rica e surpreendente viagem por múltiplas histórias do pós-abolição na Bahia e no restante do Brasil, eles com certeza não verão essa questão com os mesmos olhos. Navegando serenamente em um mar de depoimentos, testemunhos e perspectivas, Albuquerque revela como esse processo de racialização - contestado, vivido e negociado por todas as camadas sociais - aconteceu e, afinal, como foi dissimulado. A sutileza desse processo precisa de uma historiadora bastante astuta para desvendá-lo, e é exatamente isto o que faz a autora, em um texto meticulosamente bem elaborado.

Assim, vemos como o curso da abolição é profundamente marcado por recriações e disputas sobre a ideia da "raça". Não somente os intelectuais, mergulhando nas correntes "científicas" do período, vão incorporar estas novas formas de ver e agir, mas toda a sociedade participa deste processo de racialização, ao tentar estabelecer seu "lugar" (p. 31) no Brasil pós-emancipação. A racialização atinge mesmo o futuro político do país, pois as diferentes atitudes sobre "raça" marcam de maneira profunda (se bem que sempre dissimulada) as posições sobre a grande questão da monarquia/ república.

O livro é construído em torno de quatro episódios principais. A partir de cada um deles, a autora elabora sua análise junto com um "mosaico" (p. 43) de outras histórias e vozes. O primeiro capítulo conta a história de 16 libertos africanos que chegaram a Salvador desde Lagos (já protetorado britânico) em 1877, com a intenção de aproveitar suas conexões atlânticas (forjadas no intenso tráfico entre as costas do Brasil e da África) para estabelecer negócios na Bahia. Apesar do forte apoio do cônsul britânico, que os defende como "súditos [britânicos] de cor preta" ${ }^{1}$, o pedido é rejeitado por várias camadas das autoridades

\footnotetext{
* Professora de História da América Latina na Universidade de Edimburgo, Escócia.

${ }^{1}$ Para outra análise dessa linguagem, usada por cônsules britânicos e apropriada pelos próprios "súditos," ver: Jorge L. Giovannetti, "Black British Subjects in Cuba: Race, Ethnicity, Nation and Identity in the Migratory Experience, 1898-1938" (dissertação de doutorado, London Metropolitan University, 2001).
} 
brasileiras, desde o chefe de polícia local até o Conselho do Estado. A análise revela o empenho em evitar a chegada de imigrantes negros ao Brasil - independentemente de sua condição legal ou potencial benefício econômico para o país - e igualmente, a diligência empregada em "dissimular" essas motivações fundamentadas em uma lógica racial. A autora nos lembra que essas figuras do Conselho do Estado são as mesmas que estão tomando decisões-chaves sobre o processo emancipacionista.

Esse mesmo processo é enfocado no segundo capítulo, que indaga como a abolição, um pouco antes e logo depois do dia 13 de maio, foi racializada. Lançando mão de diversas fontes, particularmente as policiais, Albuquerque analisa as várias reações dos libertos à abolição, o medo sentido pelas elites, e a tentativa destas por construir um futuro em que se pudesse "preservar a palavra senhor" (pp. 121-2), com todo o peso oriundo de uma sociedade escravista. Analisam-se, aliás, as negociações e conflitos no nível cultural. O povo baiano comemorava tanto a abolição como a independência do Brasil invocando os caboclos, símbolos de um Brasil indígena e afro-brasileiro, e isto nada agradava às elites empenhadas em impor sua visão de um futuro "moderno" e culturalmente mais "branco".

O capítulo 3 nos remete ao turbulento 15 de junho de 1889, quando chegam ao porto de Salvador - viajando, incrivelmente, no mesmo barco - o Conde d'Eu e o republicano radical Silva Jardim. Olhando o incidente desde múltiplos ângulos, Albuquerque nos mostra como as diferenças entre os principais partidos políticos eram traçadas por contornos raciais. Os rachas produzidos entre republicanos brancos e os (segundo eles) "bárbaros corações iludidos" (p. 163) da Guarda Negra, integrada por carregadores do porto e liderada por figuras como Macaco Beleza (uma poderosa figura negra com relações com políticos e chefes locais), frequentemente refletiam profundas diferenças de visões raciais. Todos haviam sido "abolicionistas" até o dia 13 de maio, aliados na mesma causa, mas um episódio como o "Massacre do Taboão" mostra como eram diferentes essas visões do Brasil pós-abolição.

No quarto capítulo, vemos como a escravidão e a abolição eram lembradas pelo povo baiano através do símbolo da "África". Recriando "Áfricas" múltiplas e complexas, e negociando constantemente as políticas dessas representações com as autoridades locais, os grupos carnavalescos construíam novos sentidos da memória do passado escravista e novas construções de cidadania para o futuro.

Além da contribuição sobre a racialização - e ao mesmo tempo vinculada intimamente com ela -, o livro fornece outro aporte importante para a historiografia, ao adotar uma nova perspectiva sobre a abolição. A autora tende sempre a enfatizar a complexidade das conexões e das negociações, e é essa abordagem que a ajuda a desvelar as imbricações existentes dentro do "abolicionismo" no Brasil. O livro enxerga muito além dos impasses ocorridos, às vezes, na literatura, entre abolicionistas brancos - inicialmente heroicos, depois esquecidos ou demonizados -, por um lado, e escravos que resistem e criam novos sentidos de liberdade, pelo outro; ou entre a dádiva e o fraude, para citar o prólogo de Maria Clementina Pereira Cunha (pp. 20-21). Albuquerque mostra que é possível 
- e necessário - voltar a pensar no abolicionismo enfatizando como esse movimento era influenciado por um vasto elenco de atores sociais e políticos, cujas ideias e ações não se encaixavam em definições estanques, e que negociavam, discordavam e procuravam estampar suas múltiplas visões raciais sobre o processo da abolição. Ao convidar exescravos, abolicionistas negros, integrantes de clubes carnavalescos e o próprio Ruy Barbosa a sentarem juntos no banquete da história, Albuquerque não comete o erro de esquecer as extremas diferenças de poder existentes entre eles - diferenças, estas, que influenciariam como a perspectiva de cada um seria adotada, "dissimulada" ou esquecida pela história. Mas essa abordagem é capaz de revelar como o esforço para a abolição era um espaço bem amplo e complexo, envolvendo a sociedade brasileira como um todo. Esperamos que futuras gerações de historiadoras/es sigam a pista da autora para "mais pesquisas sobre a abolição e seus desdobramentos no Brasil" (p. 244). Sugerimos, por exemplo, que uma leitura de gênero, integrada à perspectiva de raça, seria interessante, revelando talvez que o medo das elites ante "incêndios de canaviais e estupros" (p. 135), a preocupação com aspectos como "honra e pudor das famílias" (p. 120), ou a decisão de permitir o desfile da figura da "Cabocla" sedutora mas não do "Caboclo" masculino e rebelde (p. 129), refletem um medo não só dos negros e dos ex-escravos, mas também da masculinidade negra. Neste sentido, outro grupo que, no futuro, poderia ser chamado ao "banquete" em números maiores são as mulheres, de qualquer identificação racial ${ }^{2}$. Estes são só alguns dos muitos caminhos abertos pelo livro para novas e necessárias pesquisas.

A grande questão que fica na mente dos leitores após terminar o livro é a seguinte: se 0 jogo da dissimulação revela tanto desacordo e fluxo em torno do 13 de maio; tantas tentativas de dar visibilidade ou valorizações diferentes à questão racial; e tantas tentativas de colocar os ex-escravos como cidadãos, onde isso tudo foi parar? Em certa medida, podemos remeter à "dissimulação" do título da obra em resposta a essa pergunta. Mas a sensação de surpresa ante uma "dissimulação" tão incrivelmente eficaz dá novo peso às últimas palavras da autora: "é preciso tornar mais evidentes os mecanismos que... impossibilitariam os homens [e as mulheres?] de cor de verem seus filhos retirados das 'profundas trevas' a que a ausência de cidadania os relegou' (p. 244).

\footnotetext{
${ }^{2}$ Para algumas abordagens que procuram aplicar uma perspectiva de gênero à questão da abolição, ver Roger A. Kittleson, "Women and Notions of Womanhood in Brazilian Abolitionism", in eds. Pamela Scully and Diana Paton, Gender and Slave Emancipation in the Atlantic World, 99-140 (Durham: Duke University Press, 2005); e pelo mesmo autor, “'Campaign of All Peace and Charity': Gender and the Politics of Abolitionism in Porto Alegre, Brazil, 1846-1888." Slavery and Abolition, 22 (2001): 83-108.
} 